\title{
Spatial and temporal scale framing of a decision on the future of the Mactaquac Dam in New Brunswick, Canada
}

\author{
Kate H. Reilly ${ }^{1}$ and Jan F. Adamowski ${ }^{1}$
}

\begin{abstract}
Many large dams are coming to the end of their lifespans and decisions must be made about whether to rebuild/refurbish or remove them, which will have different implications across temporal and spatial scales. Such decisions are often controversial, but little is known about what drives differences in stakeholders' perspectives of them. Cognitive scale frames describe how people use scales in interpreting such an issue, including which of its elements they prioritize and which they minimize. Using interviews with 30 stakeholders and analysis of documents, we explored how stakeholders used spatial and temporal scales in their frames of a decision about whether to rebuild/refurbish or remove the Mactaquac Dam in New Brunswick, Canada. We found that stakeholders used multiple levels on spatial, hydrological, administrative, and temporal scales in their frames. Both those who wanted to retain the dam and those who wanted to remove it upscaled problems from local level to higher spatial levels, making problems seem widely shared and therefore legitimate. However, there were mismatches in the scales used: the retainers upscaled to the province on the administrative scale while the removers upscaled to the entire river on the hydrological scale. The results revealed the particular importance of temporal scale frames, particularly of the past, which have been little studied. Both groups framed problems as continuing into the future, but diverged strongly in how they framed various periods of the past as being relevant to understanding problems and their solutions in the present. Decision makers should be aware of differing scale frames when designing decision-making processes and conflict resolution efforts.
\end{abstract}

Key Words: dams; scale framing; spatial scale; temporal scale

\section{INTRODUCTION}

Dams that were built in the early to mid-1900s are now beginning to reach the end of their lifespans (World Commission on Dams 2000). Therefore, dam owners must decide whether they should be rebuilt/refurbished or removed altogether. Removal is increasingly considered a viable choice because of the cost of rebuilding dams that may no longer provide useful functions or have become a risk to public health and safety, and because removal can restore the original river environment (World Commission on Dams 2000, Doyle et al. 2003, Gowan et al. 2006, Fox et al. 2016). However, many of these dams still offer benefits in stabilizing water supply, generating hydropower, and controlling flooding (World Commission on Dams 2000, Poff and Hart 2002), as well as enhancing river transportation and some recreational boating and fishing (Auerbach et al. 2014).

Although these end-of-life decisions on dams are taking place at a time when stakeholder participation is a priority for environmental decision makers (Reed 2008, Freeman et al. 2010, Susskind 2013, Kochskämper et al. 2016), stakeholders' perceptions of the decisions and their impacts have been little studied (Born et al. 1998, Johnson and Graber 2002, Lejon et al. 2009, Jørgensen and Renöfält 2012, Fox et al. 2016, Reilly and Adamowski 2017). There is a need to better understand why stakeholders often have diverging views on whether a dam should be removed or rebuilt/refurbished to anticipate and mediate any resulting conflict and to incorporate their perspectives into decisions (Johnson and Graber 2002, Lejon et al. 2009, Jørgensen and Renöfält 2012, Fox et al. 2016).

The concept of cognitive frames is a useful way to understand stakeholders' perceptions of a decision, particularly when diverging frames can contribute to conflict (Lewicki 2003, Dewulf et al. 2009). A frame describes how a person makes sense of a particular issue or experience, in terms of which aspects they prioritize or deem important, and which they consider unimportant (Lewicki 2003, Dewulf 2013). Therefore, understanding stakeholders' frames of an issue, such as a decision on a dam's future, reveals their position, but also their justification of that position, their assumptions, and biases, and points of agreement with other stakeholders (Lewicki 2003, Shmueli et al. 2006, Dewulf 2013).

How stakeholders frame environmental issues in terms of scale is beginning to receive particular attention (Kurtz 2003, Mansfield and Haas 2006, van Lieshout et al. 2011, Juerges and Newig 2015). Scale framing, as this process is known, means "the process of framing an issue using a certain scale and/or level" (van Lieshout et al. 2011). Scale frames may be particularly relevant to decisions on the future of dams because the decision will have impacts across multiple levels and scales (Hart et al. 2002, Cash et al. 2006, Moss and Newig 2010, Termeer et al. 2010). For example, ecological responses to dam removal differ according to the length of time since removal, i.e., according to different levels on the temporal scale (Hart et al. 2002, Hansen and Hayes 2012). In the days to years following removal, water levels go down and sediment transport increases, while years to decades later, plant community succession occurs (Hart et al. 2002). Similarly, responses are different at the site level and the river level (Hart et al. 2002, Van Looy et al. 2014). Removing a dam may affect specific salmon spawning or feeding sites, while allowing fish to migrate throughout the river system (Durance et al. 2006, Morley et al. 2008). On the administrative scale, such decisions have implications at several levels including energy policy at provincial 
or national level, and municipal-level service provision. Stakeholders use these levels and scales to define the problems associated with the decision and identify their solutions. The resulting scale frames have consequences for which arguments and stakeholders are considered legitimate to be included in the decision, potentially contributing to conflict between people with different views (McCann 2003, van Lieshout et al. 2011). Despite the importance of scale issues in decisions about dams' futures, they have not been studied to date.

We investigated how stakeholders, including business owners, anglers, boaters, and property owners, used scale to frame a decision on whether to remove or rebuild the Mactaquac Dam, a large hydropower dam on the Saint John River, New Brunswick, Canada. Its lifespan was shortened because of a structural problem with its powerhouse and spillway, although it is still functional (NB Power 2014, Stantec 2016). This case study is an interesting example of a decision on the future of a dam since, because of its shorter lifespan, the decision is occurring at a time when both the predam state and the construction of the dam are in living memory. It would also be one of the largest dam removal projects globally if that option were chosen, and therefore offers a useful example for decisions on other large dams. To study scale framing in this context, we addressed the following research questions:

- How do local stakeholders use scale to frame the problems and solutions associated with the dam, its current river environment, and its potential removal?

- How do local stakeholders use scale framing strategies to construct their arguments about whether the dam should be removed or not?

- What are the implications of the scale frames and framing strategies used for decision making about the dam?

\section{CONCEPTUAL FRAMEWORK}

We developed a conceptual framework using the literature on frames of environmental issues in decision making, and on scale frames as part of the politics of scale, as shown in Figure 1 and elaborated below. Using the literature on issue framing, we distinguished problem and solution frames, because the distinction allowed us to identify how scale is used to link the two, and to compare similar frame types when assessing mismatches between stakeholders' frames. We identified a range of scale framing strategies and their implications from the literature on scale frames in environmental decision making, which allowed for a systematic identification of frames in the data.

\section{What gets framed}

We focus here on stakeholders' frames of the problems and solutions at the center of decisions on dams at the end of their lifespan, rather than the frames of identities, relationships with others, or interaction processes that have been studied elsewhere (Dewulf et al. 2009). It is these problem and solution frames that are typically subject to scale framing as people attempt to change the legitimacy of certain arguments and stakeholders in a decision-making process (van Lieshout et al. 2011, Juerges and Newig 2015).
Fig. 1. Conceptual framework describing what aspects of the decision on the dam get framed using scale, which framing strategies are used, and the likely consequences of the frames.

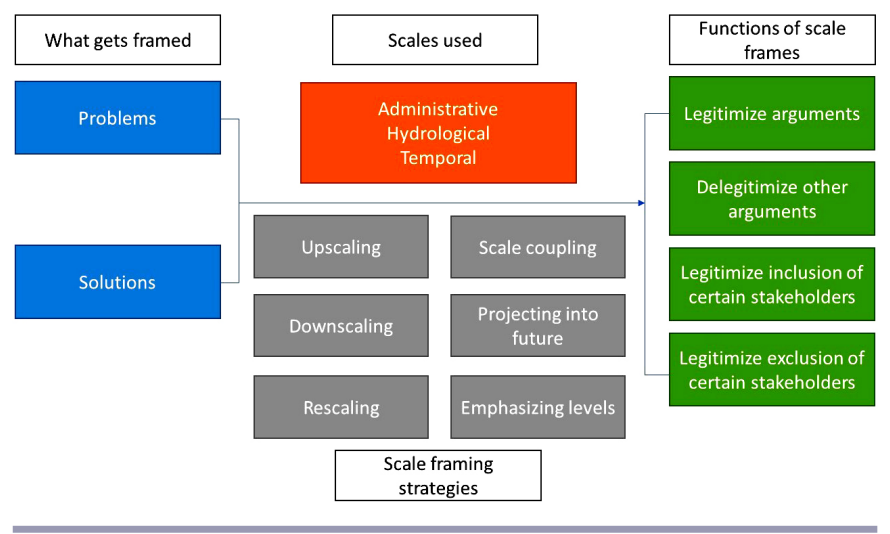

We define problem and solution frames as cognitive structures that highlight certain aspects of a situation, minimize others, and determine its boundaries, thereby forming a model of reality stored in memory (Lewicki 2003, Shmueli et al. 2006, Dewulf et al. 2009). Through this process, a person makes sense of, or interprets, the situation. In doing so, they define the debate, including the causes of the problem and who is to blame, and justify particular solutions as being appropriate or legitimate (Lewicki 2003, Dewulf 2013). Frames also serve a strategic purpose to persuade others, reinforce a position, or communicate a message (Zald 1996, Scheufele 1999, Gray and Putnam 2003).

Problem frames define whether there is a problem at the center of the decision-making process and what that problem is (Bardwell 1991, Lewicki 2003, Asah et al. 2012a). These problem frames incorporate people's "preconceptions and assumptions that underpin how one approaches the problem," which then point to a particular solution (Bardwell 1991:605). For example, a study of frames of river restoration projects found that some residents framed the projects as problems that would reduce accessibility to the floodplain, and negatively impact cultural heritage and agricultural productivity. These residents opposed river restoration. Others framed the projects as increasing the aesthetic attractiveness and natural value of the floodplains, and thus supported river restoration (Buijs 2009). Therefore, identifying problem frames reveals where exactly stakeholders diverge in their interpretation of a problem that leads to them favoring different solutions (Bardwell 1991, Asah et al. 2012a).

Solution frames include both frames of a particular solution and frames of how a decision should be made (Lewicki 2003, Juerges and Newig 2015). They are closely linked to problem frames; how a person conceptualizes a problem and which elements of the problem they consider most relevant will relate to how they frame solutions (Bardwell 1991). Frames of how a particular decision should be made often reflect a person's views on collaborative versus expert-led decision making, as well as their preferences for conflict resolution (Lewicki 2003, Peterson 2005). Understanding solution frames can help decision makers identify which strategies stakeholders agree and disagree on, rather than focusing on their fundamental differences (Asah et al. 2012b). 


\section{Using scale in problem and solution frames}

We define scales as "the spatial, temporal, quantitative or analytical dimensions used to describe a phenomenon" (Gibson et al. 2000, van Lieshout et al. 2012:164), a definition used in the study of environmental change from both ecological and social perspectives (Gibson et al. 2000). Several scales are relevant to understanding and managing environmental problems, including various spatial scales that describe how ecological and geographical processes occur in space (Fig. 1; Cash et al. 2006). In this case, the hydrological scale is the most relevant of these to the problem at hand, namely how rebuilding or removing a dam affects a river. The administrative scale refers to the "clearly bounded and organized political units" (Cash et al. 2006) in which environmental problems are managed, including municipalities, provinces, and nations. Last, the temporal scale is highly relevant because the impacts of environmental problems, and their management, frequently vary over different periods of time (Sayre 2005).

On each of these scales, there are numerous locations or units of analysis, which we refer to as levels (Gibson et al. 2000, Cash et al. 2006, Sayre and Di Vittorio 2009). For example, a day would be a level on a temporal scale and a watershed is a level on a spatial scale (Cash et al. 2006, Daniell and Barreteau 2014). Levels can be understood as a sequence of spaces arranged in a nested hierarchy (Delaney and Leitner 1997), but not all scales consist of levels arranged in this way (Gibson et al. 2000).

These scales and levels are used in framing problems and their solutions, a process known as scale framing (Kurtz 2003, Harrison 2006, Mansfield and Haas 2006, van Lieshout et al. 2011, 2012, Edge and Eyles 2014). Scale frames therefore describe how stakeholders define the boundaries of problems and solutions in space and time (van Lieshout et al. 2011, Edge and Eyles 2014). Stakeholders use scale frames to change the relative importance of levels and scales, and/or to change or reinforce power relations (Delaney and Leitner 1997, Kurtz 2003, McCann 2003, Harrison 2006, Leitner et al. 2008). For example, McCann (2003) studied the politics of scale in a neighborhood planning process. Residents argued that how the city defined the boundaries of the neighborhood promoted gentrification and marginalized longterm residents, and instead argued that the boundaries should be widened to include a larger area. Although the city's boundaries were ultimately adopted, it was only after a lengthy conflict. This strategic reconfiguration of scales to meet particular ends, whether done intentionally or unintentionally, is called the politics of scale (Leitner et al. 2008, Hüesker and Moss 2015).

\section{Scale framing strategies}

Several strategies by which scale frames are used to meet political goals in environmental decision making have been identified (Fig. 1; McCann 2003, van Lieshout et al. 2012, Juerges and Newig 2015, Sica 2015). The simplest is to emphasize a particular level, such as the regional or national level, in framing an issue, which has the effect of prioritizing the interests or issues found at that level (van Lieshout et al. 2014). Upscaling and downscaling involve shifting the interpretation of an issue to higher or lower levels on the same scale, respectively. They are often used in solution scale framing to argue for a change in the level at which decision making or governance of an issue occurs (Kurtz 2003,
Harrison 2006, van Lieshout et al. 2012, Juerges and Newig 2015). For example, environmental organizations in Germany argued that decisions about windfarms should be taken at state level, rather than local level, to avoid local-level economic concerns overriding environmental protection (Juerges and Newig 2015). They can also be used in problem frames to magnify an issue and make it seem widely shared by upscaling it to a higher level, or minimize it by downscaling it to a lower level (van Lieshout et al. 2012, Sica 2015).

Rescaling involves shifting the scale used to frame either problems or solutions associated with an issue (van Lieshout et al. 2014, Juerges and Newig 2015). Like upscaling and downscaling, it can be used to argue for a change in governance by changing the scale on which an issue is framed, such as from the administrative to a biophysical scale (Hüesker and Moss 2015, Juerges and Newig 2015). An example of rescaling is the current focus on watersheds (a level on a hydrological scale) as a more appropriate unit for water management than municipalities or states/provinces (levels on an administrative scale; Hüesker and Moss 2015). Scale coupling involves linking two or more scales together to produce a stronger argument for a particular outcome (McCann 2003, van Lieshout et al. 2012).

On the temporal scale, the strategy of future projection involves referring to future conditions to justify an argument about a decision in the present. Such projections can include anticipations of regret if a decision is made in a certain way, promises of future benefits, and projected changes that will require a particular action now (van Lieshout et al. 2012). For example, in a debate over a megafarm in the Netherlands, the responsible municipal council member argued for a megafarm on the basis that the municipality would regret it if they chose not to allow the farm (van Lieshout et al. 2012). This strategy has been little studied in terms of how different periods in the future are framed and its implications.

\section{Functions of scale frames}

At a general level, scale framing strategies are used to shift power and authority, to realize interests, or to advocate for particular solutions based on perceptions of effectiveness, efficiency, or legitimacy (Kurtz 2003, McCann 2003, van Lieshout et al. 2011, 2014). In this way, scale is used to frame a problem so that a particular solution appears logical or, conversely, inappropriate (Williams 1999, Harrison 2006, Mansfield and Haas 2006, van Lieshout et al. 2011).

One of the ways in which scale framing a problem can be used to support or reject a particular solution is in using scale to legitimize or delegitimize arguments. Arguments can be legitimized for example by magnifying their importance or making them appear widely shared. Van Lieshout et al. (2011) identified that the developer of the Dutch megafarm framed the farm as a model for the rest of the world to follow, i.e., framing it at global level. In doing so, he described its benefits as being more important than his own personal interests and made its development seem an obvious solution. Such scale frames therefore legitimize arguments that may be difficult to justify had they not been framed using that scale or level (van Lieshout et al. 2011). 
Scale frames can also be used to argue for a change in the level at which a solution is implemented. For example, the need to restrict water retention in storage dams in the Murray-Darling Basin was framed as an important issue at sequentially higher levels, from local to state to national level. This resulted in the decision to limit water retention being taken by the federal government, which allowed the state government to avoid political consequences from irrigators who viewed the restriction as an injustice (Patrick et al. 2014) In this way, how issues are framed using scales and levels has implications for decision making and conflicts between stakeholders (Delaney and Leitner 1997, van Lieshout et al. 2011, Patrick et al. 2014).

By defining the boundaries of a problem in time and space, scale frames also justify the inclusion or exclusion of groups of people as being amongst those affected by the issue. Upscaling can be used to portray a larger group of people as affected by an issue, and therefore reinforce the need for it to be addressed (Kurtz 2003, Harrison 2006, van Lieshout et al. 2014). For example, activists campaigning against pesticide exposure in farm workers upscaled it from farm level to state level, which strengthened their case for action (Harrison 2006). Scale framing, particularly downscaling, can also have the opposite function: in framing an issue at a particular level, some people are described as outsiders, allowing their arguments to be dismissed (Kurtz 2003).

\section{Implications of scale framing strategies and their outcomes for environmental decision making}

Frames of environmental decision making have important consequences for understanding problems, identifying effective solutions, and conflict resolution, particularly when they diverge between stakeholders. Frames that incorporate distinct understandings of a problem lead to different solutions being favored, and prevent other solutions being explored (Bardwell 1991). Such divergences in how problems and solutions are framed can cause difficulties in communication and contribute to conflict (Lewicki 2003, Shmueli et al. 2006, Dewulf et al. 2009). New information is interpreted through the frame, which further reinforces it, and therefore hinders efforts to encourage frame convergence (Shmueli et al. 2006). Furthermore, when a frame defines what is right or fair, its user can blame others who they perceive as contributing to the injustice (Lewicki 2003). These processes can solidify differences between stakeholders in conflict.

Scale frames, in particular, are the subject or source of disputes between stakeholders as they attempt to change scalar arrangements or advocate for a particular solution with scalar implications (Delaney and Leitner 1997). These disputes can take the form of mismatches between scale frames, meaning that stakeholders' scale frames of a problem or solution are incompatible (Termeer et al. 2010, van Lieshout et al. 2011). Van Lieshout et al. (2011) identified three types of mismatches between stakeholders' scale frames: (1) framing an issue differently but using the same level or scale, (2) framing the issue using a different scale, and (3) framing the issue using a different level. When different stakeholders use mismatching frames to argue for opposite solutions, communication difficulties can arise and conflict can be initiated or exacerbated (van Lieshout et al. 2011).
Understanding the assumptions and contradictions in how stakeholders scale frame a situation can allow areas of agreement, and hence compromise, to be identified, expand the range of possible solutions, and facilitate negotiation and mediation efforts (Bardwell 1991, Shmueli et al. 2006, Asah et al. 2012a, Emery et al. 2013). It can also inform reframing efforts or collaborative processes to create a shared understanding of the situation. This shared understanding can then provide the foundation for addressing other elements of the conflict (Schön and Rein 1995, Asah et al. 2012a, van Hulst and Yanow 2016).

The various scale framing strategies and their functions outlined above have been investigated in a range of contexts, including agricultural issues and renewable energy (Harrison 2006, van Lieshout et al. 2011, 2012, 2014, Juerges and Newig 2015). We study them in a unique context: the potential removal of a large dam that would have varying consequences across time and space. We also build on the few studies that investigate how an issue is framed using different scales, including spatial, administrative, hydrological, and temporal scales, as opposed to studying the spatial scale alone (McCann 2003, van Lieshout et al. 2011, Hüesker and Moss 2015).

\section{STUDY AREA}

\section{Choice of case}

A decision on whether to rebuild or remove the Mactaquac Dam, a hydropower dam on the Saint John River, New Brunswick, Canada, was chosen as the focus of this study. At a height of 42.37 $\mathrm{m}$ above sea level, the Mactaquac Dam is one of the largest dams ever considered for removal (Stantec 2016), making it an important test case for other decisions about large dams. Its construction significantly changed the landscape and altered how communities and individuals interacted with the river. The decision made by New Brunswick Power, the dam's owner, therefore would have significant impacts on the river and how communities and individuals interact with it, and became an important issue of local concern (Dillon Consulting 2015). Opinions on which option should be chosen diverged significantly, meaning that there was ample opportunity to observe different scale frames. Furthermore, the decision-making process was ongoing at the time of the study, which allowed frames to be identified concurrently, rather than relying on people's retrospective views of a past event.

\section{Background information}

The Mactaquac Dam is located on the middle reach of the Saint John River (Fig. 2), which runs through Quebec and New Brunswick, Canada, and Maine, United States. The dam, located approximately $20 \mathrm{~km}$ upstream of Fredericton, the capital of New Brunswick, was constructed in the 1960s and now produces approximately $12 \%$ of New Brunswick's electricity (Stantec 2016). Its construction created a reservoir, known as the Mactaquac headpond, of approximately $97 \mathrm{~km}$ in length and $84 \mathrm{~km}^{2}$ in area that extends from Hartland downstream to the dam (Fig. 2; Canadian Rivers Institute 2013, Stantec 2016). Fredericton is the largest population center in the area; the area around the headpond is primarily rural with several small towns, including Nackawic and Woodstock. The study was focused on the river reach from Hartland upstream to Fredericton downstream because this area was the most affected by the dam's construction. 
Fig. 2. Study area: St John River from Hartland (upstream) to Fredericton (downstream), New Brunswick, Canada. Inset: Location of study area (in orange) within province of New Brunswick. Source: Reilly and Adamowski 2017.

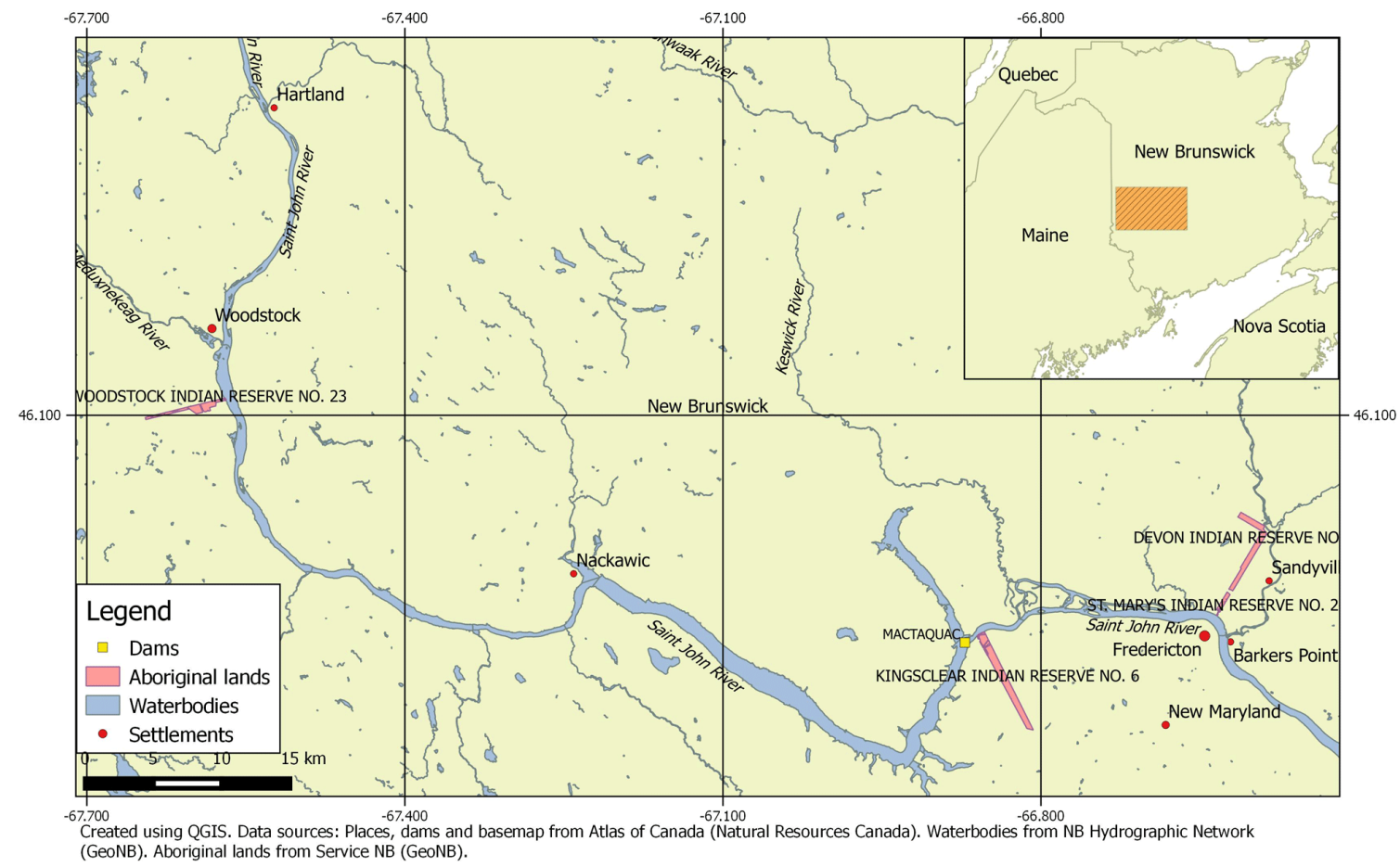

\section{Impacts of the Mactaquac Dam}

The dam impacted the area from Hartland to Fredericton hydrologically, ecologically, socially, and economically. The headpond is deeper and has a slower water velocity than the river prior to being dammed, creating a more lake-like environment. Downstream flow has also been affected; because water is released through the dam in response to fluctuating energy demands, water levels change by up to $1 \mathrm{~m}$ over the course of a day (Canadian Rivers Institute 2011, Luiker et al. 2013, Jones 2014). Some of the ecological impacts of the dam are related to this change in hydrology. The oscillations in downstream flow can dislodge benthic taxa, and salmon smolt cannot navigate the headpond because of its slow velocity and shallow gradient (Carr 2001, Canadian Rivers Institute 2011, Luiker et al. 2013, Jones 2014). The dam is a barrier to upstream migration for several species, including American shad (Alosa sapidissima) and Atlantic salmon (Salmo salar; Canadian Rivers Institute 2011).

Many local people opposed construction of the dam, including some residents both upstream and downstream of the dam site, Maliseet people, farmers, and sports fishers (Kenny and Secord 2010, Bourgoin 2013). This diverse range of stakeholders were organized into the Association for the Preservation and Development of the Saint John River in its Natural State, which regularly appealed against the dam to the public and the provincial government. Opposition arguments centered around several issues, including loss of aesthetic beauty, impacts on fisheries, flooding of valuable agricultural land, and destruction of historical and cultural heritage. For example, residents opposed the flooding of cemeteries on ethical grounds and because they represented personal and cultural connections to the past (Bourgoin 2013). Opponents' concerns were ultimately disregarded and provincial decision makers focused on the contribution the dam's energy would make to New Brunswick's economic development and modernization (Bourgoin 2013).

Approximately 900-1100 people were relocated (estimates vary; Si 1993, Bourgoin 2013) and were compensated monetarily. Some chose to move to higher ground at the same site, some moved site, and some left the area entirely ( $\mathrm{Si}$ 1993). The relocations were, for the most part, traumatic (Si 1993, Keilty et al. 2016, Sherren et al. 2016). In addition, it is estimated that 16 graveyards and nine churches were relocated. Fort Meductic, an important historical site for the Maliseet people, was flooded, as well as 2.5 acres of the Woodstock First Nation's land (Bourgoin 2013). Many farms became economically unviable when highly productive low-lying land was flooded. Approximately 100 jobs were created at the Nackawic pulp and paper mill, but the regional development project associated with the dam's construction largely failed in generating employment (Si 1993).

Since then, however, the headpond has become valuable socially and economically in itself (Sherren et al. 2016). Economic activity around the headpond mostly relies on recreation and tourism, including boating, fishing, and camping (Dillon Consulting 2015). Many new houses have been built, with residents drawn to the area by the aesthetics and recreational opportunities (Lawson et al. 1985, Dillon Consulting 2015, Stantec 2016).

Many of the residents around the headpond now feel attachment to it and feel it contributes to their sense of identity (Sherren et 
al. 2016). Individuals, including those who remember the predam river and those who moved to the area since, have adapted to the dammed landscape (Keilty et al. 2016). These individuals tend to personally value the aesthetics and recreational and business opportunities afforded by the lake-like environment (Sherren et al. 2016, Reilly and Adamowski 2017). However, there remain many others who regret the loss of many characteristics of the predam river, including the Atlantic salmon run, the low-lying farmland and islands, and its aesthetics (Reilly and Adamowski 2017).

\section{The decision on the dam's future}

The decision on whether to retain the dam in some form or remove it was required because of a structural problem in the electricity generating components of the dam that was predicted, at the time of the study in summer 2015, to shorten its lifespan from the planned 100 years to approximately 60 years. The problem is caused by an alkali-aggregate reaction between the cement and the aggregate in the concrete spillway, powerhouse, and other structures, which causes the concrete to expand. The earthen structure that impounds the river is not affected (Stantec 2016).

At the time of the study, New Brunswick Power had identified three options for the dam's future: rebuild the affected structures to maintain electricity generation and the headpond, retain the earthen dam to maintain the headpond, or remove the dam entirely to restore the river to its natural free-flowing condition. Reviews of the environmental and social impacts of each option were underway at the time of the study (Dillon Consulting 2015, Stantec 2016), but neither had yet been released to the public. Consultations with Maliseet Nations in the area were ongoing, but the public consultation had not yet started. The decision was made by the provincial power company and provincial government based on these studies and assessments of the finances, energy, and other considerations. For this study, we focused on the option to remove the dam, because it would cause greater ecological, social, and economic changes than the other two options, which would be similar to the status quo.

Numerous issues were at stake in the decision. The electricity that the dam currently produces would have to be replaced with other renewables, in order to meet New Brunswick's legislative requirements (NB Power 2016). All options had high associated costs; utility costs were estimated at 4.3 to 5.6 billion CAD depending on the option (NB Power 2017). To manage these, New Brunswick Power planned incremental rate rises for energy consumers, with the rest of the project financed with a loan from the provincial government (NB Power 2016). Numerous other economic, environmental, and social impacts of the various options were identified during New Brunswick Power's review process (Table 1).

The decision took place in a particular political and economic context. The government's debt was continuing to increase as a percentage of GDP and was expected to increase to $42 \%$ in 2017/2018 (RBC 2017). The province experienced a decline in population of $0.5 \%$ between 2011 and 2016 (Statistics Canada 2017), which, combined with an increasing number of retirees, made growing and maintaining the population a provincial priority (Government of New Brunswick 2014). To address these challenges, the provincial government was focused on promoting economic growth, including through investing in infrastructure projects (Government of New Brunswick 2016).
Table 1. Economic, environmental, and social issues of concern in the Mactaquac Dam project (Dillon Consulting 2015, Stantec 2015).

\begin{tabular}{|c|c|}
\hline Impact category & Particular concerns \\
\hline $\begin{array}{l}\text { Atmospheric } \\
\text { environment }\end{array}$ & $\begin{array}{l}\text { Air quality, greenhouse gas emissions, } \\
\text { microclimate }\end{array}$ \\
\hline Acoustic environment & Sound quality and vibration \\
\hline Surface water & $\begin{array}{l}\text { Flow regime, water quality, sediment quality, } \\
\text { flooding, }\end{array}$ \\
\hline Groundwater & Groundwater quantity and quality \\
\hline Aquatic environment & $\begin{array}{l}\text { Fish habitat, fish mortality, species at risk, } \\
\text { species of conservation concern }\end{array}$ \\
\hline Vegetation and wetlands & $\begin{array}{l}\text { Vegetation communities, species at risk, } \\
\text { species of conservation concern, wetland area } \\
\text { and function }\end{array}$ \\
\hline $\begin{array}{l}\text { Wildlife and wildlife } \\
\text { habitat }\end{array}$ & $\begin{array}{l}\text { Wildlife habitat, direct mortality, species of } \\
\text { conservation concern }\end{array}$ \\
\hline $\begin{array}{l}\text { Economy and } \\
\text { employment }\end{array}$ & $\begin{array}{l}\text { Economic activity including local businesses, } \\
\text { employment }\end{array}$ \\
\hline Resource uses & $\begin{array}{l}\text { Land and resource use, navigation, exposure } \\
\text { of land/islands, land acquisition }\end{array}$ \\
\hline $\begin{array}{l}\text { Community and social } \\
\text { uses }\end{array}$ & $\begin{array}{l}\text { Access to recreational uses, community } \\
\text { identity, property values, viewshed changes, } \\
\text { river access }\end{array}$ \\
\hline $\begin{array}{l}\text { Infrastructure and } \\
\text { services }\end{array}$ & $\begin{array}{l}\text { Infrastructure, access, water intakes and } \\
\text { outfalls, community emergency services, } \\
\text { housing and accommodation, infrastructure } \\
\text { damage }\end{array}$ \\
\hline Transportation & $\begin{array}{l}\text { Road infrastructure, traffic volume, } \\
\text { disruption }\end{array}$ \\
\hline Heritage resources & $\begin{array}{l}\text { Archaeological, historical, and } \\
\text { palaeontological resources }\end{array}$ \\
\hline $\begin{array}{l}\text { Use of land and } \\
\text { resources for traditional } \\
\text { purposes by Aboriginal } \\
\text { persons }\end{array}$ & Traditional use \\
\hline
\end{tabular}

Given the wide-ranging impacts of all options, the decision was divisive socially. A group of residents in the headpond area formed a citizen's action group to advocate for retaining the headpond, it was much discussed in local media, and meetings held by New Brunswick Power were well attended (Keilty 2015, NB Power 2015, Sherren et al. 2016). The majority of residents and stakeholders around the headpond appeared to be in favor of rebuilding the dam, as evidenced by opinions voiced at community meetings and in New Brunswick Power's consultation process (NATIONAL AND CRA 2016, Sherren et al. 2016). For some, this was because of a desire to avoid going through trauma from removal similar to that which occurred when the dam was built (Sherren et al. 2016). Other key arguments in favor of rebuilding the dam included a desire to maintain the business and recreational opportunities of the headpond, minimize impacts on property values, avoid disturbing the headpond ecosystem, and maintain hydropower generation (Sherren et al. 2016, Reilly and Adamowski 2017). However, some stakeholders and up- and downstream residents expressed desire to remove the dam to restore Atlantic salmon populations, enhance biodiversity and the river's sustainability, and reinstate the opportunity for farming on low-lying land (Reilly and Adamowski 2017). 


\section{METHODS}

\section{Data collection}

We used semistructured interviews as the primary method of data collection. This allowed us to identify the details of participants' opinions and experiences, which may not have been revealed by a quantitative survey (Patton 2005). The interviews were semistructured to ensure that the same topics were addressed in every interview, while allowing interviewees the freedom to broach other subjects. We triangulated the interview data with data from documents to determine the consistency of results across methods (Creswell and Miller 2000, Yin 2003). Documents have the advantage of revealing people's perspectives without any input from the researcher (Creswell and Miller 2000, Gray 2004).

We interviewed 30 individuals, most of whom were located between Woodstock and Fredericton (Fig. 2). They were selected using nonproportional quota sampling (Patton 2005) to ensure that the sample included the greatest range of opinions on the future of the dam. We therefore aimed to include individuals located throughout the study area, and representing the main parties in the decision, including First Nations, anglers, headpond residents, downstream residents, industry, businesses, environmental nongovernmental organizations (NGOs), watershed organizations, heritage groups, and recreational groups. The final sample, however, did not include any interviewees located between Woodstock and Hartland, but did include two located outside the study area who had strong professional and/or personal interests in the area. Industry and representatives of First Nations declined to participate. Possible reasons for this include insufficient time or resources to participate, lack of interest, or in the latter case, prior involvement with New Brunswick Power's consultation. None of the stakeholders included in the sample had direct decision-making power but all had the ability to influence the decision through New Brunswick Power's consultation process. Some were involved in organizations operating at the provincial level, while the majority were focused on the local level.

Twenty-one of the participants were interviewed individually and nine in groups, at their own request; all were conducted between May and July 2015. All but one were conducted in person in the study area, at a location of the participant's choosing. The remaining interview was conducted by Skype. We continued to conduct interviews until theoretical saturation was reached, meaning that interviewees introduced no new themes (Strauss and Corbin 1998). It should be noted, however, that the inclusion of representatives of First Nations and industry in the sample may have introduced new themes.

In each interview, lasting 45 minutes to an hour, we addressed the participant's role and interest in the area and the decision, how they used the river in the study area, their opinions on the dam's future, and their perceptions of each option's impacts. The participants were not directly asked about scale (Apostolopoulou and Paloniemi 2012). Each main theme was introduced with an open-ended question, and closed questions were used where necessary to ensure understanding. Because most of the interviewees had multiple interests in the decision, through their professional and personal lives, they chose which perspective they were most comfortable talking from (Lewan and Söderqvist 2002, Lamarque et al. 2011). Reasons for their choice included whether the organization they were involved with had developed a position on the dam and the extent to which they were personally affected. Most talked from multiple perspectives and made that clear in their answers.

We collected documents through Google searches, using the keywords "Mactaquac" and "Mactaquac Dam," and from online versions of local newspapers, namely the Fredericton Daily Gleaner, the Saint John Telegraph Journal, and the Woodstock Bugle-Observer. All relevant documents were retained for background information, and a subset were used for analysis. We included in this subset all documents published between August 2014 and August 2015 that included the author's opinion on what should happen to the dam, as opposed to background facts, with sufficient information for us to identify their frames. This time period was chosen because it was long enough to include several documents, and it ended when information on the decision was published by New Brunswick Power and the consultation period began. In this way, we ensured that the writers of the documents had access to similar information on the decision as the interviewees. We excluded any documents that repeated opinions that were published in a very similar form elsewhere. The final sample included 19 documents, including blog posts, comments in online forums, editorials, and letters to the editor.

\section{Data analysis}

We coded the transcribed interviews and documents in RQDA, a qualitative data analysis package in $\mathrm{R}$ (Huang 2014). In a combined deductive-inductive approach, we used the conceptual framework to develop a codebook of problem and solution frames, and hydrological, administrative, spatial, and temporal scales. We used the codebook to code the data by identifying passages where problems or solutions were framed, and determining if scale(s) were used in the framing. Based on the data, we modified the codebook by subdividing the codes into different problem and solution types, and by dividing the scales into levels, based on an inductive analysis of the data. This was an iterative process of coding, revising the codebook, checking the consistency of passages coded with the same code and their distinctions with other codes, and recoding. We ultimately coded the data using a codebook that included several problem and solution subtypes, and divisions of each scale into levels (Table 2).

The coded data was then summarized into a table with a line for each participant and a column for each subtype of problem and solution frame to allow systematic comparison between participants. The various scales and levels a participant used to frame each subtype were entered into the corresponding cell. We then identified how the problem and solution frames were constructed. To do this, we looked for how arguments either for or against dam removal were constructed by identifying which scales and levels were used to describe perceived issues, and whether those issues were all perceived in the same direction, i.e., positive or negative. If they were described in the same direction they were considered part of a scale framing strategy, as described in the conceptual framework. By comparing the direction of argument, levels and scales used, links between those levels and scales, and scale framing strategies across participants, we identified the most common scale frames used to construct arguments. 
Table 2. Indicators for scale and level codes, adapted from (van Lieshout et al. 2011).

\begin{tabular}{|c|c|c|}
\hline Code & Definition & Indicators \\
\hline Problem - current & $\begin{array}{l}\text { Descriptions of aspects of the current condition of } \\
\text { the river, i.e., with the dam in place, as problematic. }\end{array}$ & $\begin{array}{l}\text { Perceived problems associated with the current } \\
\text { dammed river or with the current environmental, } \\
\text { social, economic, political context, including } \\
\text { continuing historical problems. }\end{array}$ \\
\hline Problem - removal & $\begin{array}{l}\text { Descriptions of removal of the dam and the } \\
\text { resulting river condition as problematic. }\end{array}$ & $\begin{array}{l}\text { Perceived problems, in either the dammed river or } \\
\text { the broader context, associated with removal of the } \\
\text { Mactaquac Dam. }\end{array}$ \\
\hline Solution - rebuilding & Arguments in favor of rebuilding the dam & $\begin{array}{l}\text { Reasons why the dam should be rebuilt that are not } \\
\text { linked to problems associated with removal. }\end{array}$ \\
\hline Solution - removing & Arguments in favor of removing the dam. & $\begin{array}{l}\text { Reasons why the dam should be removed that are } \\
\text { not linked to problems associated with the current } \\
\text { state. }\end{array}$ \\
\hline Solution - decision making process & $\begin{array}{l}\text { Perceptions of how the decision on the dam's future } \\
\text { should be made. }\end{array}$ & $\begin{array}{l}\text { Preferences for how the decision should be made, } \\
\text { including participation, scientific studies, etc., as well } \\
\text { as perceptions of how the decision will be made. }\end{array}$ \\
\hline Hydrological scale - river level & $\begin{array}{l}\text { The entire river system from source to sea, including } \\
\text { tributaries and at-sea processes. }\end{array}$ & $\begin{array}{l}\text { References to the Saint John River system and its } \\
\text { watershed, its hydrology and ecology, management } \\
\text { of the river, other dams, the salmon run, flooding as } \\
\text { an issue in the entire river system. Impacts of the } \\
\text { dam downstream. }\end{array}$ \\
\hline $\begin{array}{l}\text { Spatial/hydrological scale - headpond } \\
\text { level }\end{array}$ & $\begin{array}{l}\text { The headpond as a component of the hydrological } \\
\text { system and as a spatial unit (the two could not } \\
\text { always be distinguished in the data). The headpond } \\
\text { refers to the reservoir upstream of the dam. }\end{array}$ & $\begin{array}{l}\text { References to the headpond as a body of water, its } \\
\text { recreational opportunities and aesthetics, its } \\
\text { hydrological and ecological functions, as a } \\
\text { community. References to the reach that is currently } \\
\text { the headpond after removal. }\end{array}$ \\
\hline Spatial scale - global level & The world or planet as a spatial unit. & $\begin{array}{l}\text { References to the global hydrological system, global } \\
\text { issues, global climate change, being a world leader. }\end{array}$ \\
\hline Spatial scale - national level & $\begin{array}{l}\text { The nation of Canada as a spatial unit, but not } \\
\text { when referred to as an administrative unit. }\end{array}$ & $\begin{array}{l}\text { References to issues as common across the country, } \\
\text { being a national leader. }\end{array}$ \\
\hline Spatial scale - local level & $\begin{array}{l}\text { Local areas, including parks and towns, but not } \\
\text { when referred to as an administrative district. }\end{array}$ & $\begin{array}{l}\text { References to communities, towns, parks, etc., issues } \\
\text { arising in those locations. }\end{array}$ \\
\hline Spatial scale - property level & A house or property as a spatial unit. & $\begin{array}{l}\text { References to issues at an individual property or } \\
\text { house, including their land. }\end{array}$ \\
\hline $\begin{array}{l}\text { Spatial/administrative scale - provincial } \\
\text { level }\end{array}$ & $\begin{array}{l}\text { The province as an administrative unit and as a } \\
\text { spatial unit (the two could not always be } \\
\text { distinguished from the data). }\end{array}$ & $\begin{array}{l}\text { References to New Brunswick, the provincial } \\
\text { government, provincial policies, issues common to } \\
\text { the province, costs to the province, energy } \\
\text { generation. }\end{array}$ \\
\hline Administrative scale - municipal level & A city, village, or town as an administrative district. & $\begin{array}{l}\text { References to town politics, municipal services, } \\
\text { municipal taxes. }\end{array}$ \\
\hline Time scale - future level & Any period of time any length in the future. & $\begin{array}{l}\text { References to sustainability, future generations, } \\
\text { lengths of time in the future. }\end{array}$ \\
\hline Time scale - past level & Any period of time any length in the past. & $\begin{array}{l}\text { References to the dam's construction, the period of } \\
\text { time before the dam, the period of time since the } \\
\text { dam, history, etc. }\end{array}$ \\
\hline
\end{tabular}

\section{RESULTS}

We identified several scale frames of problems associated with the current river condition and with removal of the dam, as well as several solution scale frames, using spatial, hydrological, administrative, and temporal scales (Fig. 1). Those who wanted to retain the dam (hereafter the retainers) focused on recreation, aesthetics, energy, tourism, and property values and related tax issues, among others:

I see the beauty of the lake and the recreational value of the lake [...]. The loss of those will be, I think, a tremendous cost and it will have some impact on tourism economics (Participant 25; retainer).

Those who wanted to remove the dam (hereafter the removers) also discussed recreation, aesthetics, and tourism, but emphasized biodiversity, river connectivity, Atlantic salmon populations, farmland, and sustainability:

Thinking about the interconnection of the main stream with the tributaries and the life that flows, and the nature of the river and the flowing water, and how it is such a great catalyst to all kinds of biodiversity, to me it's a no brainer (Participant 15; remover).

The frames identified in this section were shared between participants within the subgroups. However, as previously noted, the sample did not include some key groups in the study area, namely Maliseet First Nations communities or organizations and industry. Therefore, the analysis of frames presented here illustrates how scales and scale framing strategies can be used in framing problems and solutions associated with the dam, rather 
Table 3. Removers' scale frames of the problem of the dam.

\begin{tabular}{|c|c|c|c|c|c|}
\hline Frame & Name & Description & Scales and levels used & $\begin{array}{l}\text { Scale framing } \\
\text { strategy used }\end{array}$ & Quote \\
\hline A & $\begin{array}{l}\text { What has happened to } \\
\text { the dammed reach (the } \\
\text { headpond) has } \\
\text { happened to the river }\end{array}$ & $\begin{array}{l}\text { Problems caused by the dam } \\
\text { upscaled from local level and/or } \\
\text { headpond level problems to the } \\
\text { Saint John River system. }\end{array}$ & $\begin{array}{l}\text { Spatial-hydrological } \\
\text { Spatial }\end{array}$ & Upscaling, rescaling & $\begin{array}{l}\text { "They (NB Power) have [...] } \\
\text { completely eliminated salmon } \\
\text { runs in the Saint John River" } \\
\text { (Participant 18; remover). }\end{array}$ \\
\hline B & $\begin{array}{l}\text { The provincial context } \\
\text { is negative }\end{array}$ & $\begin{array}{l}\text { Problems at provincial level that } \\
\text { are not directly caused by the } \\
\text { dam but will have implications } \\
\text { for the decision, including neglect } \\
\text { of the environment and } \\
\text { provincial debt. }\end{array}$ & Spatial-administrative & Emphasizing level & $\begin{array}{l}\text { "It's building a dam versus } \\
400 \text { million in deficit. It's } \\
\text { what the priority? } \\
\text { (Participant } 17 \text {; remover). }\end{array}$ \\
\hline $\mathrm{C}$ & $\begin{array}{l}\text { The dam is not } \\
\text { sustainable }\end{array}$ & $\begin{array}{l}\text { Problems caused in the future by } \\
\text { the dam remaining in place. }\end{array}$ & Temporal & Future projection & $\begin{array}{l}\text { "A natural river is } \\
\text { sustainable. A manmade dam } \\
\text { is not" (Participant 29; } \\
\text { remover). }\end{array}$ \\
\hline $\mathrm{D}$ & $\begin{array}{l}\text { The predam state was } \\
\text { better than the current } \\
\text { situation }\end{array}$ & $\begin{array}{l}\text { The state of the river before the } \\
\text { dam was built was better than the } \\
\text { current one, and has since been } \\
\text { forgotten. }\end{array}$ & Temporal & Past interpretation & $\begin{array}{l}\text { "Certainly, the lament for the } \\
\text { loss of what was lost in the } \\
1960 \text { s was for a reason, I } \\
\text { think. And over time, over } 50 \\
\text { years, I guess people forget, } \\
\text { or they've never even } \\
\text { experienced it" (Participant } \\
\text { 15; remover). }\end{array}$ \\
\hline
\end{tabular}

than offering a comprehensive inventory of all scale frames used. In the remainder of this section, we describe the various problem and solution frames identified, the scales used, and the scale framing strategies inherent in them (Fig. 1). The outcomes or functions of the scale frames are interpreted in the discussion.

\section{Problem scale frames}

Consistent with their positions, the retainers' problem frames focused on problems that would be caused by the removal of the dam, while the removers mainly framed the current situation as a problem. Although some members of each group acknowledged problems associated with their chosen option for the dam, those problems did not contribute to the participant's central argument:

\section{I would certainly sympathize with the landowners up on the Mactaquac Lake [the headpond]. That would be a mess (Participant 21; remover).}

We focus here on the most commonly used problem scale frames, although there were other less common frames, including the emphasis of some retainers on the local level problems caused by dam removal.

\section{Scale frames of the current situation as a problem}

Several scale frames of the current river condition with the dam in place were used by removers to build their argument that the dam should be removed. These frames used spatial, hydrological, administrative, and temporal scales, and involved the scale framing strategies of upscaling, rescaling, emphasizing level and future projection, as well as interpretation of the past (Fig. 1 and Table 3).

Of the two spatial scale frames, frame A was more common. The negative impacts of the construction and presence of the dam were upscaled and rescaled from local (spatial scale) or headpond level (spatial-hydrological scale) to the river level (hydrological scale). This upscaling and rescaling served to put the issues caused by the dam in the context of the hydrological system of the Saint John River as a whole.

Some participants referred to the same issues at each level, while others referred to different issues. For example, participant 15 discussed the river no longer being a community focal point since the dam was built (local level), increasing populations of invasive species (headpond level) and a loss of biodiversity (river level):

Local level: Guys [...] used to, after work they'd keep their fishing poles and their rods in their cars, and after supper they would just head to the river. It was just a place that, it was kind of living and a focal point of existence much more so than now.

Headpond level: The other thing the headpond did was [...] generate the ability for invasive species to take off.

River level: It sort of doesn't live and breathe and function like a river should. I mean, it's not a natural thing anymore. To me (Participant 15; remover).

Frame B did not discuss the direct impacts of the dam on the province, but emphasized the provincial level by outlining its negative characteristics as the context in which the decision would take place. Short-term thinking, a bias toward job creation rather than the environment, and population decline were mentioned:

If you read anything about New Brunswick, everything they say, "there will be jobs." There might be jobs only for six months, but there are jobs. And the change that they make may last for a hundred years or may last for a thousand, but there were jobs for the first year and that's all they ask (Participant 18; remover). 
Table 4. Retainers' spatial and temporal scale frames of the problem of dam removal.

\begin{tabular}{|c|c|c|c|c|c|}
\hline Frame & Name & Description & Scales and levels used & $\begin{array}{l}\text { Scale framing strategy } \\
\text { used }\end{array}$ & Quote \\
\hline 1 & $\begin{array}{l}\text { What happens to the } \\
\text { headpond happens to } \\
\text { the province }\end{array}$ & $\begin{array}{l}\text { Impacts at property and local } \\
\text { level upscaled to headpond } \\
\text { level and then again to } \\
\text { provincial level. }\end{array}$ & $\begin{array}{l}\text { Spatial-hydrological } \\
\text { Spatial-administrative } \\
\text { Spatial }\end{array}$ & Upscaling, rescaling & $\begin{array}{l}\text { "If they take it down, it would } \\
\text { be the largest dam ever removed } \\
\text { anywhere in the world. So here } \\
\text { we are with } 750,000 \text { people, how } \\
\text { do we pay for it? From a realistic } \\
\text { point of view, } 2 \text { billion dollars to } \\
\text { tear it down would break the } \\
\text { province" (Participant 23; } \\
\text { retainer). }\end{array}$ \\
\hline 2 & $\begin{array}{l}\text { The headpond is the } \\
\text { center of the decision }\end{array}$ & $\begin{array}{l}\text { The headpond level was } \\
\text { emphasized, with no upscaling } \\
\text { to provincial level. Issues at } \\
\text { property or local level may have } \\
\text { been upscaled to headpond } \\
\text { level. }\end{array}$ & $\begin{array}{l}\text { Spatial } \\
\text { Spatial-hydrological }\end{array}$ & Emphasizing level & $\begin{array}{l}\text { "Without the dam, without the } \\
\text { draws that are beside the dam, } \\
\text { the, the tourism, the park, the } \\
\text { camping, the lodges, and small } \\
\text { businesses that have grown up } \\
\text { because of the accessibility, this } \\
\text { whole area in the dam area } \\
\text { would be devastated without the } \\
\text { water being there" (Participant } \\
\text { 08; retainer). }\end{array}$ \\
\hline 3 & $\begin{array}{l}\text { The future after } \\
\text { removal will not be } \\
\text { pleasant }\end{array}$ & $\begin{array}{l}\text { Future framed only in terms of } \\
\text { the transition period } \\
\text { postremoval. No posttransition } \\
\text { period envisaged. }\end{array}$ & Temporal & Future projection & $\begin{array}{l}\text { "If they let the water out, there's } \\
\text { no way on earth you'll ever grow } \\
\text { grass on that" (Participant 06; } \\
\text { retainer). }\end{array}$ \\
\hline 4 & $\begin{array}{l}\text { The past cannot be } \\
\text { restored }\end{array}$ & $\begin{array}{l}\text { Focuses on the predam past } \\
\text { and frames it as being } \\
\text { irretrievable. }\end{array}$ & Temporal & Past interpretation & $\begin{array}{l}\text { "You get some of the nostalgic } \\
\text { crowd that, "we'll get our land } \\
\text { back." Well, you won't get the } \\
\text { land back. NB Power bought the } \\
\text { land. It was all bought and paid } \\
\text { for" (Participant 14; retainer). }\end{array}$ \\
\hline 5 & Postdam adaptation & $\begin{array}{l}\text { Focuses on postdam past and } \\
\text { frames it as being stable, and } \\
\text { wanting to avoid disruption of } \\
\text { dam construction period. }\end{array}$ & Temporal & Past interpretation & $\begin{array}{l}\text { "Most people don't want it to } \\
\text { go, because there are still some } \\
\text { around who went through it the } \\
\text { first time and, I understand, it } \\
\text { was horrible" (Participant 19). }\end{array}$ \\
\hline
\end{tabular}

When constructing temporal scale frames, both retainers and removers divided the past into three main periods: predam construction, dam construction, and postconstruction to present. They divided the future into two periods: a period of ecological and social transition after dam removal, and a more stable posttransition period. The length of time that each period in the future represented was not constant and was subject to framing by the participants.

Two temporal scale frames of the current situation as a problem were identified, one which looked to the future (frame $\mathrm{C}$ ) and one which referred to the past (frame D). The participants using frame $\mathrm{C}$ projected the problems caused by the dam into the future (scale framing strategy; Fig. 1), thereby accentuating their significance. These participants referred to the costs of maintaining a dam over time and the unsustainable nature of a dammed river compared to a free-flowing river, and argued that removal was necessary to avoid these long-term damages. For example, participant 18 argued that the long-term future was not given sufficient weight in decisions to the detriment of the environment:

When you build a dam and they do all these costs, they don't measure the losses. They don't say you're going to lose salmon for the next thousand years, five hundred years (Participant 18; remover).
Frame D referred to the past before the dam was constructed, using a strategy of past interpretation that was not identified in the conceptual framework (Fig. 1). The participants using this frame argued that the predam state should be relevant to the decision but that many people do not remember its positive condition and that it is minimized in the decision-making process. They described its positive characteristics in terms of the aesthetics, agricultural potential, and environmental benefits of the river valley before the dam was built:

Even in the spring, the cakes of ice that used to flow, you used to hear them and see them and it was spectacular. Now it's not. Because it's just Mactaquac Lake (Participant 15; remover).

Therefore, frame D interprets the past in a way that enhances its relevance to the decision made in the present.

Scale frames of removal as a problem

We similarly identified both spatial and temporal scale frames of problems associated with dam removal (Table 4), which were mostly used by retainers in constructing their arguments against removal. On the spatial scale, frame 1 was used most frequently. Like frame A, it involved upscaling and rescaling negative impacts of the perceived problem as scale framing strategies (Fig. 1). However, participants using this frame upscaled from the 
headpond level (spatial-hydrological scale) to the provincial level (spatial-administrative scale), rather than to the river level on the hydrological scale as was the case for frame A. Some participants using frame 1 started by discussing impacts at their property or their town (local level, spatial scale), before arguing that those impacts would also occur throughout the headpond (headpond level, spatial-hydrological scale). They then upscaled again to the provincial level, (spatial-administrative scale). Others only upscaled from the headpond level to the province, without discussing the local level.

Like frame A, some participants referred to the same issues when upscaling, including lower property values from loss of waterfront, and reduced tourist numbers because of recreational losses. For example, Participant 02 described the impacts on property values:

Property and headpond level: I can't imagine that they will bring [the river] back. Because if that happens, then the property values will be way lower. And that will affect many, many people [...]. Your house isn't valued as much if you don't have a big piece of waterway out there, if you only have a mud flat.

Provincial level: If your home value goes down, the government is not going to be able to tax you. So they're going to lose money (Participant 02; retainer).

Others used a sequence of different issues at each level to construct their argument. Although the issues attributed to each level were different, they were all described as causing negative impacts:

Property level: In front of my house there's a 90 foot drop to the gorge. That is going to be 90 feet of mud. Bare rock and mud.

Headpond level: [Removal] would affect the fish because you would have a tremendous loss of volume of water [in the headpond].

Provincial level: If they take it down, it would be the largest dam ever removed anywhere in the world. So here we are with 750,000 people, how do we pay for it? From a realistic point of view, 2 billion dollars to tear it down would break the province (Participant 23; retainer).

Frame 2 also involved using the spatial scale to frame dam removal as a problem, but emphasized the headpond level or upscaled from property/local level to the headpond level but no further. For example, Participant 06 had numerous concerns about removal for the headpond area, but did not refer to any implications at higher levels:

My main concern is the devastation of the value that people have put in their homes and their businesses and so on that surround the headpond for another 50 miles upriver. If it's not there then business is just going to go down, because, it's like all these other places, that campground and so on, there'd be no reason for people to be there if the headpond's gone (Participant 06; retainer).

On the temporal scale, frame 3 projected negative impacts of dam removal into the future (scale framing strategy; Fig. 1), and particularly focused on the transition period between removal of the dam and the river "re-establishing itself." For example, they described the newly dewatered land as being muddy and smelly rather than being revegetated, and were concerned about fish deaths during the draining process. Although their perceptions of the length of time it would take for the area to be in an acceptable condition varied, they all implied it would be too long, and dismissed the possibility of any eventual restoration. For example, Participant 19 thought the area would be in an unacceptable condition forever:

I've heard people say, "it'll be all green again in a year and it'll be fine." I don't believe that. I think it's had years and years of muck and silt and, I just doubt it'll ever be good for much of anything (Participant 19; retainer).

Two frames involved a strategy of interpreting the relevance of the past to the current decision. Frame 4 focused on the predam past, which is defined as irrelevant to the decision, while frame 5 focused on the postconstruction past, which is deemed central to the decision. The participants using frame 4 argued that specific attractive aspects of the predam past, including the Atlantic salmon fishery and agriculture on the low-lying land, could not be restored even if they were desirable:

We know what the economy was before the dam, it was subsistence farming and small farms and a little bit of lumbering. [...] But when that disappears, when the water goes back down, that's not going to come back (Participant 09; retainer).

Frame 5 by contrast focuses on the recent past postdam construction and has two main components: a desire to avoid both the pain of the dam's construction in the first place, and disruption of the social, ecological, and economic adaptation that has taken place since. For example, Participant 05 describes the disruption associated with the construction of the dam:

I think from a social, economic point of view we'd be creating a disaster similar to what happened in the $60 \mathrm{~s}$ when they created the headpond (Participant 05; retainer).

Therefore, these frames, in combination with frame 3 , frame the present as the best condition the area could be in, and argue in favor of preserving it.

Mismatches in scale frames of problems

We identified all three mismatches in van Lieshout et al.'s (2011) typology between the problem frames used by the retainers and the removers (Table 5). All three were present between the spatial scale frames: mismatches in framing an issue at a particular level, mismatches in the scales used to frame an issue, and mismatches in the levels used to frame an issue. On the temporal scale, there were mismatches in both how a level was framed and in the levels used to frame an issue.

There were both level and scale mismatches between frame A and frame 1 because they upscaled to different higher levels, the river level for removers and the provincial level for retainers, and used different scales, the hydrological scale and the spatial/ administrative scale respectively:

They've created a very nice recreational spot [in the headpond] but they've completely eliminated salmon runs in the Saint John River (Participant 18; remover; upscaling to the river). 
Table 5. Summary of mismatches between the various scale frames identified.

\begin{tabular}{|c|c|c|c|c|}
\hline \multirow[b]{2}{*}{ Retainers' frames } & \multicolumn{4}{|c|}{ Removers' problem frames } \\
\hline & Frame A & Frame B & Frame C & Frame D \\
\hline Frame 1 & $\begin{array}{l}\text { Scale mismatch } \\
\text { (hydrological vs } \\
\text { administrative) } \\
\text { Level mismatch (headpond } \\
\text { to river vs headpond to } \\
\text { province) }\end{array}$ & None & None & None \\
\hline Frame 2 & $\begin{array}{l}\text { Level mismatch (river vs } \\
\text { headpond) }\end{array}$ & None & None & None \\
\hline Frame 3 & None & None & $\begin{array}{l}\text { Scale frame mismatch } \\
\text { Level mismatch (post } \\
\text { transition vs transition } \\
\text { period) }\end{array}$ & None \\
\hline Frame 4 & None & None & None & Scale frame mismatch \\
\hline Frame 5 & None & None & None & $\begin{array}{l}\text { Level mismatch (predam past } \\
\text { vs postdam past) }\end{array}$ \\
\hline
\end{tabular}

They [the government] know what's going to happen [if they take the dam out ], they will have a lawsuit they can't afford from all the people on the headpond (Participant 13; retainer; upscaling to the province).

Therefore, while both frames involved the same strategies (upscaling and rescaling), they were employed differently in constructing the arguments.

There were also significant mismatches in the levels used and how they were framed on the temporal scale (Fig. 3). The removers framed the predam past and the posttransition period as being positive and the most relevant to the decision, and linked them together: dam removal would enable the positive aspects of the predam past to be restored. The retainers, by contrast, described dam construction as traumatic, which should not be replicated during the removal process. They also focused on the transition period, which would disrupt the positive aspects of the dammed river. Therefore, the two groups did not agree on whether each time period would be negative or positive, nor on which periods were most relevant to the decision-making process.

\section{Solution scale frames}

The scale frames used to argue in favor of a preferred solution reflected those used to define problems. For example, the retainers particularly emphasized the headpond level, and sometimes upscaled to the provincial level (scale framing strategies; Fig. 1), in their solution scale frames:

If they go to the full deal, the restore electricity, it's the largest project the province has ever seen (Participant 14; retainer).

Some projected the benefits of hydropower to the long-term future:

It's clean, dependable, the river goes on and on and on. It'll be here long after I've gone and it'll still be producing power (Participant 23; retainer).

The removers also used the same scale frames to argue for removal as they used to argue that the current river condition was a problem, while some also upscaled the benefits of removal from the local level and/or the headpond level to the provincial level.
The scale frames of how the decision should be made were less clear-cut and varied both within and between groups. For some of the removers, the key factor in the decision making should be the future or long-term benefits of the option chosen, and they therefore emphasized this level on the temporal scale:

Think beyond the four-year term and just think objectively about what's the best decision for the future (Participant 15; remover).

Some retainers also used future projection to determine how the decision should be made, but focused specifically on long-term hydropower benefits:

I think the ongoing value of the energy generation is a big, big factor that has to be measured carefully (Participant 25; retainer).

Members of both groups emphasized the provincial level when discussing how the decision should be made by arguing that either provincial residents should be asked directly, in a vote or referendum, or that the provincial government should decide on behalf of the electorate. For example, participant 18 argued the following:

We live in a democracy, so sort it out to the point where, if more people want it than don't want it, then that's what they do (Participant 18; remover).

Participant 16, a retainer, agreed:

They should have a public vote or referendum in the province and do it that way.

However, some retainers thought this might be risky because residents of other parts of the province might not want to keep the dam. For some of those retainers, this was a reason to reject holding a provincial vote, whilst others acknowledged the risk but did not change their mind:

Even though probably that could work against us, because I'm sure there's lots of people in Moncton or Saint John that would probably say take it out. Take the dam out. And that would be the views of the public as well (Participant 22; retainer). 
Fig. 3. Mismatches in temporal scale framing between rebuilders and removers. Green bars/arrows represent perceptions of a period of time as positive, while red bars/arrows represent negative perceptions. Yellow bars are neutral. The length of the bars relative to the timeline at the top of the figure represent participants' perceptions of the length of each time.

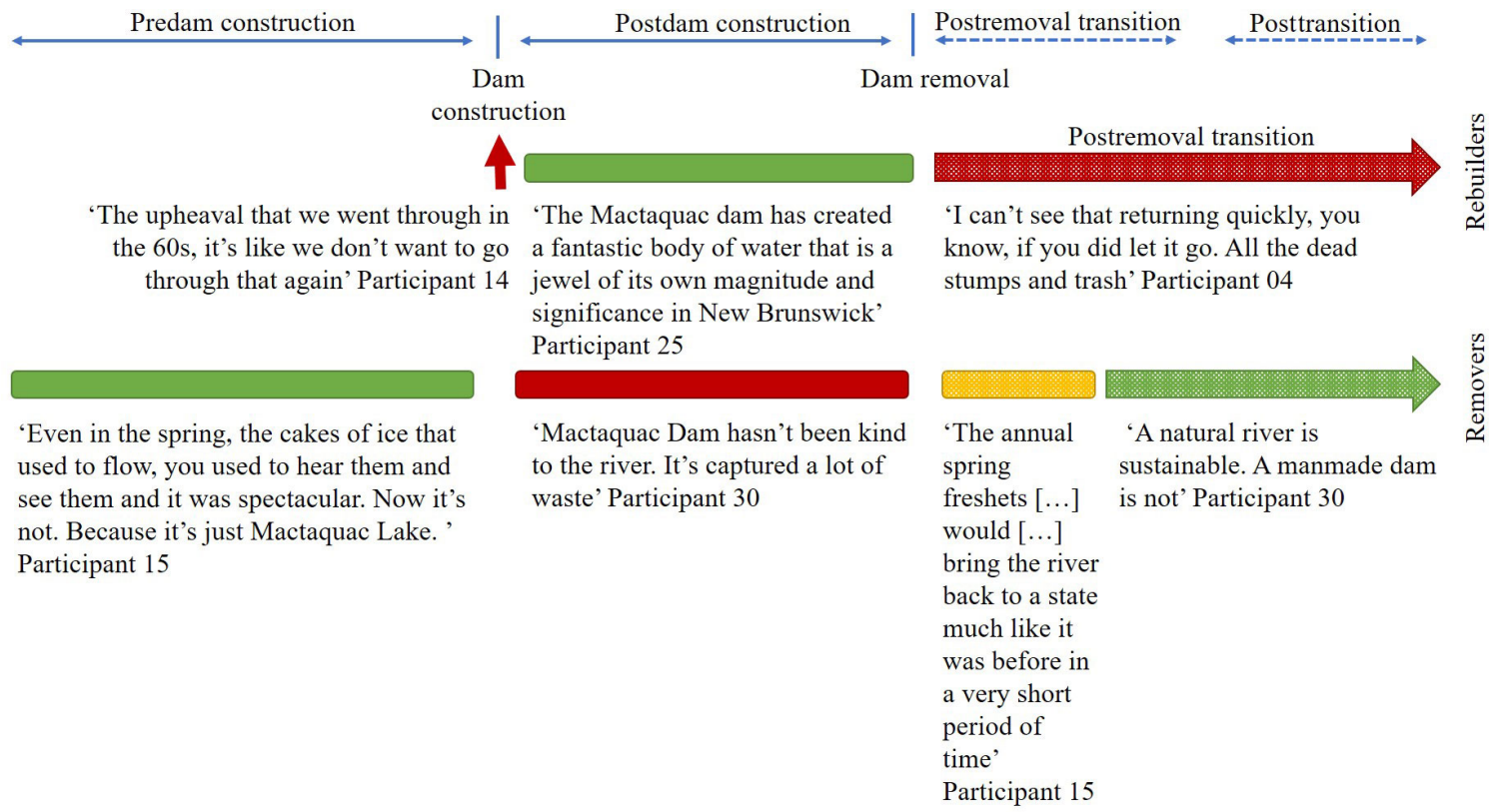

Those retainers that did not want a provincial vote were explicit that this was because they wanted the headpond to be the focus in the decision making in a process of downscaling:

There's a lot of general public that have never even seen the Mactaquac headpond and they would be just voting on how they feel about rivers and how they feel about dams $[. .$.$] , not totally understanding the whole impact$ of everything (Participant 01; retainer).

\section{DISCUSSION}

In this study, we aimed to demonstrate how different stakeholders used scale to frame problems and solutions associated with the dam and its potential removal. The results show that stakeholders in both groups, the retainers and the removers, framed problems using both spatial and temporal scales, but used them in different ways. The study of scale frames illuminates not only how stakeholders interpret the problem in general (Reilly and Adamowski 2017), but how they define its boundaries in space and time.

\section{The roles of scales and strategies in scale framing}

The results show that the participants in the study sample used similar scales and scale framing strategies to frame problems and solutions associated with the dam. Both groups used spatial, hydrological, administrative, and temporal scales in their frames, and employed the strategies of upscaling, rescaling, emphasizing levels, projecting to the future, and interpreting the past. However, the combinations of scales and strategies used in framing a problem or solution were different between the participant groups, in ways that had consequences for decision making.
The scales and strategies used in problem and solution framing (Fig. 1), including upscaling and future projection, had implications for which arguments were legitimized and which were delegitimized, and which stakeholders were deemed relevant to the decision and which were excluded (Kurtz 2003, Harrison 2006, van Lieshout et al. 2011, Sica 2015). The retainers perceived that they would be personally affected by removal, through loss of recreational access and property values, for example (Reilly and Adamowski 2017). However, they upscaled these personal impacts to the headpond and then the provincial level, as well as projecting them to the postremoval future. This served to magnify the importance of the impacts of removal beyond their personal interests. In doing so, the retainers using this scale frame assumed that other households and towns around the headpond area, as well as future generations, would be affected by the same impacts and experience them in the same way. The removers used a similar process to highlight the impacts beyond those on the ecosystem services that they benefit from or value (Reilly and Adamowski 2017), by discussing how those impacts affect the whole river system. In this way, both groups broadened their argument beyond their personal interests (Kurtz 2003, van Lieshout et al. 2011). The study, therefore, offers evidence that scale framing can be present and can affect which arguments are legitimized and which stakeholders are included in decision-making processes around dams, in addition to the agricultural, energy, and industrial contexts previously studied (Kurtz 2003, Harrison 2006, van Lieshout et al. 2011, Sica 2015).

The results of this study revealed divergences in temporal scale framing. The participants had different interpretations of the condition, relative importance, and duration of different time 
periods in the past and the future. Although temporal scale framing is less studied in the literature on the politics of scale than spatial frames, the results provide support for McCann (2003) and van Lieshout et al.'s $(2011,2012,2014)$ suggestion that time plays a role in the politics of scale. In particular, we suggest that interpretation of the past is an important scale framing strategy, somewhat analogous to future projection (van Lieshout et al. 2012); although the importance of frames of the past have been identified, they have been little studied (McCann 2003, Reed and Bruyneel 2010). Depending on how the past is framed, it makes some solutions seem possible and/or desirable, while portraying others as unjust. For example, the removers' frames of the predam past produce an attractive vision of what the river could be postremoval, and portray this choice as an opportunity to regain what was lost in the dam's construction. By contrast, the retainers' frames of the dam's construction as traumatic, and the period since as stable, foreclose the option of removal. It may also have implications for which groups of people are perceived to have the authority or legitimacy to define the relevance of the past (McCann 2003).

The study provided support for van Lieshout et al.'s (2011) typology of scale frame mismatches, of which we found evidence for all three: mismatches in framing the issue at different levels on the same scale, framing the issue on different scales, and using different scale frames. The disparate use of scale in problem framing reinforces differences between participants in how they frame the decision around the dam in general (Reilly and Adamowski 2017). Mismatches can further hinder a shared understanding of the problem to be addressed, by disputing which levels are most affected and how impacts on different scales are related. They can obscure the interests at stake, and create divisions between stakeholders (Mansfield and Haas 2006, van Lieshout et al. 2011, Juerges and Newig 2015).

Finally, by differentiating problem and solution frames we identified participants' attempts to link the level of a problem to the level at which decisions about it are made (Towers 2000, Kurtz 2003, Harrison 2006). For example, in their upscaling of the problem of dam removal to provincial level, some retainers intentionally or unintentionally connected the level of the problem to the level of decision making, i.e., provincial level. This process of matching the "scales of meaning," i.e., the problem frames, to "scales of regulation," i.e., the solution frames, has been identified as a strategy used by groups seeking environmental justice, as a tactical way of making their claims relevant to decision makers (Towers 2000, Kurtz 2003). Some of our results also suggest that the converse process can occur to match the "scale of regulation," the solution frame, to the "scale of meaning," the problem frame (Juerges and Newig 2015). For example, other retainers downscaled their solution frames, arguing against a provincial vote on the basis that people in other parts of the province would not properly consider the impact of the decision on the headpond. The extent to which this reverse strategy occurs in other contexts and its implications deserves further study.

Overall, therefore, the study suggested that findings on scale framing and its implications in other contexts are also applicable to decisions on the future of dams, and that the temporal scale, particularly the past, is an important component of scale framing. However, the study cannot provide an exhaustive typology of the scale frames present in the debate around the future of the Mactaquac Dam. This is for two reasons. Although the sample was purposefully small, to allow an in-depth exploration of the details of stakeholders' frames, and sought to include all perspectives, two key groups, First Nations and industry, did not participate. The inclusion of First Nations and industry in the sample could be expected to introduce new scale frames, and potentially new scale framing strategies. Furthermore, the data was collected during a single period during the decision-making process. It does not account for any changes in scale framing or strategies used during the consultation period or after the decision was made.

\section{Implications of scale framing for making end-of-life decisions for dams}

Dam construction, and subsequent removal or replacement, has implications across spatial and temporal scales (Hart et al. 2002, Cash et al. 2006, Moss and Newig 2010, Termeer et al. 2010). Although these implications may be assessed as part of technical or environmental reviews of the options for a dam at the end of its life, stakeholders' frames of those scales should also be considered.

First, the different perceptions of the scale and level on which problems are or will be experienced should be reflected in the design of the decision-making process, including impact assessments and stakeholder consultations. No one scale or level will be the most appropriate (Cash et al. 2006, Juerges and Newig 2015). Decision makers should be aware that how these processes are scaled will affect how the problem is defined, which solutions are possible, and which issues and stakeholders are included or given priority (Lebel 2006, Vreugdenhil et al. 2010, Juerges and Newig 2015). The choice of scale will therefore influence stakeholders' perceptions of the legitimacy of the consultation and assessment process (Lebel 2006, Moss and Newig 2010).

Second, stakeholders' scale frames must be recognized in mediation or conflict resolution methods. Typically, such methods revolve around encouraging reframing of a topic or building on convergences between frames. However, divergence between frames not only in the issues used, but in the scales on which they are interpreted, presents an additional complication. Reframing efforts must first recognize the scales and levels used, and their implications for highlighting and concealing interests, before proceeding (van Lieshout 2014).

The results also suggest some avenues for future research. The role of temporal scale framing in decision making requires further attention. For example, future research could further investigate the extent to which temporal scale frames function in similar ways to spatial scale frames that legitimize/delegitimize arguments and include/exclude people from consideration in a decision. The interactions between spatial and temporal scale frames could also be explored in more depth. Last, temporal scale framing of the past was found here in a distinct context, in which the construction of the dam created a division in the past between the predam and postdam periods, which may be interpreted differently by stakeholders. Therefore, the relevance of scale framing of the past in other circumstances without this particular context would be worth investigation. 


\section{CONCLUSION}

This study revealed the role of scale framing in a conflict over whether a dam should be removed or not. We found that the retainers and removers used similar strategies in their spatial scale frames of the problem, including upscaling, rescaling, and emphasizing levels, but that there were mismatches in the scales used (spatial/administrative and hydrological scales, respectively), and in the levels to which problems were upscaled (province and river, respectively). These mismatches had implications for which arguments were legitimized and which stakeholders were included in the problem definition. In terms of the temporal scale, the importance of projection to the future to justify a stakeholder's argument was confirmed. We identified the significance of diverging interpretations of the past as contributing to conflict around such decisions. Authorities involved in deciding a dam's future should be aware of the upheaval caused by the dam's construction, the adaptation since, and the variations between individuals in how those periods of the past are interpreted.

Responses to this article can be read online at: http://www.ecologyandsociety.org/issues/responses. $\mathrm{php} / 9535$

\section{Acknowledgments:}

We acknowledge the support of a grant from the Canadian Social Sciences and Humanities Research Council held by Jan Adamowski. We are grateful to all interviewees for their time and participation in this study.

\section{LITERATURE CITED}

Apostolopoulou, E., and R. Paloniemi. 2012. Frames of scale challenges in Finnish and Greek biodiversity conservation. Ecology and Society 17(4):9. http://dx.doi.org/10.5751/ES-05181-170409

Asah, S. T., D. N. Bengston, K. Wendt, and L. Devaney. $2012 b$. Prognostic framing of stakeholders' subjectivities: a case of allterrain vehicle management on state public lands. Environmental Management 49(1):192-206. http://dx.doi.org/10.1007/s00267-011-9756-7

Asah, S. T., D. N. Bengston, K. Wendt, and K. C. Nelson. $2012 a$. Diagnostic reframing of intractable environmental problems: case of a contested multiparty public land-use conflict. Journal of Environmental Management 108:108-119. http://dx.doi. org/10.1016/j.jenvman.2012.04.041

Auerbach, D. A., D. B. Deisenroth, R. R. McShane, K. E. McCluney, and N. L. Poff. 2014. Beyond the concrete: accounting for ecosystem services from free-flowing rivers. Ecosystem Services 10:1-5. http://dx.doi.org/10.1016/j.ecoser.2014.07.005

Bardwell, L. V. 1991. Problem-framing: a perspective on environmental problem-solving. Environmental Management 15 (5):603-612. http://dx.doi.org/10.1007/BF02589620

Born, S. M., K. D. Genskow, T. L. Filbert, N. Hernandez-Mora, M. L. Keeper, and K. A. White. 1998. Socioeconomic and institutional dimensions of dam removals: the Wisconsin experience. Environmental Management 22(3):359-370. http://dx. doi.org/10.1007/s002679900111
Bourgoin, S. 2013. Disregarded sentiments: discovering the voices of opposition to the Mactaquac Dam. Thesis. St Mary's University, Halifax, Nova Scotia, Canada.

Buijs, A. E. 2009. Public support for river restoration. A mixedmethod study into local residents' support for and framing of river management and ecological restoration in the Dutch floodplains. Journal of Environmental Management 90 (8):2680-2689. http://dx.doi.org/10.1016/j.jenvman.2009.02.006

Canadian Rivers Institute. 2011. The Saint John River: a state of the environment report. Canadian Rivers Institute, Fredericton, New Brunswick, Canada.

Canadian Rivers Institute. 2013. Mactaquac aquatic ecosystem study - study area. Canadian Rivers Institute, Fredericton, New Brunswick, Canada. [online] URL: http://canadianriversinstitute. com/research/mactaquac-aquatic-ecosystem-study/study-area/

Carr, J. 2001. Downstream movements of juvenile Atlantic salmon (Salmo salar) in the dam-impacted St John River Drainage. Canadian Manuscript Report of Fisheries \& Aquatic Sciences No. 2573, Dept. of Fisheries \& Oceans Canada, Ottawa, Ontario, Canada.

Cash, D. W., W. Adger, F. Berkes, P. Garden, L. Lebel, and P. Olsson. 2006. Scale and cross-scale dynamics: governance and information in a multilevel world. Ecology and Society 11(2):8. http://dx.doi.org/10.5751/ES-01759-110208

Creswell, J. W., and D. L. Miller. 2000. Determining validity in qualitative inquiry. Theory Into Practice 39(3):124-130. http://dx. doi.org/10.1207/s15430421tip3903_2

Daniell, K. A., and O. Barreteau. 2014. Water governance across competing scales: coupling land and water management. Journal of Hydrology 519(PC):2367-2380. http://dx.doi.org/10.1016/j. ihydrol.2014.10.055

Delaney, D., and H. Leitner. 1997. The political construction of scale. Political Geography 16(2):93-97. http://dx.doi.org/10.1016/ S0962-6298(96)00045-5

Dewulf, A. 2013. Contrasting frames in policy debates on climate change adaptation. Wiley Interdisciplinary Reviews: Climate Change 4(4):321-330. http://dx.doi.org/10.1002/wcc. 227

Dewulf, A., B. Gray, L. Putnam, R. Lewicki, N. Aarts, R. Bouwen, and C. van Woerkum. 2009. Disentangling approaches to framing in conflict and negotiation research: a meta-paradigmatic perspective. Human Relations 62(2):155-193. http://dx.doi. org/10.1177/0018726708100356

Dillon Consulting. 2015. Social impact comparative review. Dillon Consulting, Toronto, Ontario, Canada.

Doyle, M. W., J. M. Harbor, and E. H. Stanley. 2003. Toward policies and decision-making for dam removal. Environmental Management 31(4):453-465. http://dx.doi.org/10.1007/s00267-002-2819$\mathrm{Z}$

Durance, I., C. Lepichon, and S. J. Ormerod. 2006. Recognizing the importance of scale in the ecology and management of riverine fish. River Research and Applications 22:1143-1152. http://dx.doi.org/10.1002/rra.965

Edge, S., and J. Eyles. 2014. The socio-spatial (re)configuration of legitimacy, knowledge, and practice in chemical risk 
governance: integrating boundary-work and scale-frame analytics. Environmental Politics 23(2):282-301. http://dx.doi. org/10.1080/09644016.2013.818300

Emery, S. B., M. T. Perks, and L. J. Bracken. 2013. Negotiating river restoration: the role of divergent reframing in environmental decision-making. Geoforum 47:167-177. http://dx.doi.org/10.1016/ j.geoforum.2013.01.008

Fox, C. A., F. J. Magilligan, and C. S. Sneddon. 2016. "You kill the dam, you are killing a part of me": dam removal and the environmental politics of river restoration. Geoforum 70:93-104. http://dx.doi.org/10.1016/j.geoforum.2016.02.013

Freeman, R. E., J. S. Harrison, A. C. Wicks, B. L. Parmar, and S. de Colle. 2010. Stakeholder theory: the state of the art. Cambridge University Press, Cambridge, UK. http://dx.doi.org/10.1017/ $\underline{\mathrm{CBO} 9780511815768}$

Gibson, C. C., E. Ostrom, and T. K. Ahn. 2000. The concept of scale and the human dimensions of global change: a survey. Ecological Economics 32(2):217-239. http://dx.doi.org/10.1016/ $\underline{\mathrm{S} 0921-8009(99) 00092-0}$

Government of New Brunswick. 2014. New Brunswick population growth strategy 2014-2017. Government of New Brunswick, Fredericton, New Brunswick, Canada.

Government of New Brunswick. 2016. The New Brunswick economic growth plan. Government of New Brunswick, Fredericton, New Brunswick, Canada.

Gowan, C., K. Stephenson, and L. Shabman. 2006. The role of ecosystem valuation in environmental decision making: hydropower relicensing and dam removal on the Elwha River. Ecological Economics 56(4):508-523. http://dx.doi.org/10.1016/j. ecolecon.2005.03.018

Gray, B. 2004. Strong opposition: frame-based resistance to collaboration. Journal of Community \& Applied Social Psychology 14:166-176. http://dx.doi.org/10.1002/casp. 773

Gray, B., and L. L. Putnam. 2003. Means to what end? Conflict management frames. Environmental Practice 5(3):239-246. http:// dx.doi.org/10.1017/S1466046603035634

Hansen, J. F., and D. B. Hayes. 2012. Long-term implications of dam removal for macroinvertebrate communities in Michigan and Wisconsin Rivers, United States. River Research and Applications 28:1540-1550. http://dx.doi.org/10.1002/rra.1540

Harrison, J. L. 2006. "Accidents" and invisibilities: scaled discourse and the naturalization of regulatory neglect in California's pesticide drift conflict. Political Geography 25 (5):506-529. http://dx.doi.org/10.1016/j.polgeo.2006.02.003

Hart, D. D., T. E. Johnson, K. L. Bushaw-Newton, R. J. Horwitz, A. T. Bednarek, D. F. Charles, D. A. Kreeger, and D. J. Velinsky. 2002. Dam removal: challenges and opportunities for ecological research and river restoration. Bioscience 52(8):669-682. http:// dx.doi.org/10.1641/0006-3568(2002)052[0669:DRCAOF]2.0.CO;2

Huang, R. 2014. RQDA: R-based qualitative data analysis. $R$ package version 0.2-7. The $\mathrm{R}$ Project for Statistical Computing, Vienna, Austria. [online] URL: http://rqda.r-forge.r-project.org/
Hüesker, F., and T. Moss. 2015. The politics of multi-scalar action in river basin management: implementing the EU Water Framework Directive (WFD). Land Use Policy 42:38-47. http:// dx.doi.org/10.1016/j.landusepol.2014.07.003

Johnson, S. E., and B. E. Graber. 2002. Enlisting the social sciences in decisions about dam removal. BioScience 52(8):731-738. http:// dx.doi.org/10.1641/0006-3568(2002)052[0731:ETSSID]2.0.CO;2

Jones, N. E. 2014. The dual nature of hydropeaking rivers: Is ecopeaking possible? River Research and Applications 30:521-526. http://dx.doi.org/10.1002/rra.2653

Jørgensen, D., and B. M. Renöfält. 2012. Damned if you do, damned if you don't: debates on dam removal in the Swedish media. Ecology and Society 18(1):18. http://dx.doi.org/10.5751/ ES-05364-180118

Juerges, N., and J. Newig. 2015. What role for frames in scalar conflicts? Land Use Policy 49:426-434. http://dx.doi.org/10.1016/ j.landusepol.2015.08.013

Keilty, K. 2015. Understanding landscape values and baselines of acceptability on the Mactaquac Dam and headpond, New Brunswick. Thesis. Dalhousie University, Halifax, Nova Scotia, Canada.

Keilty, K., T. M. Beckley, and K. Sherren. 2016. Baselines of acceptability and generational change on the Mactaquac hydroelectric dam headpond (New Brunswick, Canada). Geoforum 75:234-248. http://dx.doi.org/10.1016/j.geoforum.2016.08.001

Kenny, J. L., and A. G. Secord. 2010. Engineering modernity: hydroelectric development in New Brunswick, 1945-1970. Acadiensis 1(1):3-26.

Kochskämper, E., E. Challies, J. Newig, and N. W. Jager. 2016. Participation for effective environmental governance? Evidence from Water Framework Directive implementation in Germany, Spain and the United Kingdom. Journal of Environmental Management 181:737-748. http://dx.doi.org/10.1016/j.

jenvman.2016.08.007

Kurtz, H. E. 2003. Scale frames and counter-scale frames: constructing the problem of environmental injustice. Political Geography 22(8):887-916. http://dx.doi.org/10.1016/j.polgeo.2003.09.001

Lamarque, P., U. Tappeiner, C. Turner, M. Steinbacher, R. D. Bardgett, U. Szukics, M. Schermer, and S. Lavorel. 2011. Stakeholder perceptions of grassland ecosystem services in relation to knowledge on soil fertility and biodiversity. Regional Environmental Change 11(4):791-804. http://dx.doi.org/10.1007/ s10113-011-0214-0

Lawson, P. M., G. Farnsworth, and M. A. Hartley. 1985. The Nackawic Bend. Town of Nackawic, Nackawic, New Brunswick.

Lebel, L. 2006. The politics of scale in environmental assessments. Pages 37-57 in W. V. Reid, F. Berkes, T. Wilbanks, and D. Capistrano, editors. Bridging scales and knowledge systems. Island Press, Washington, D.C., USA.

Leitner, H., E. Sheppard, and K. M. Sziartot. 2008. The spatialities of contentious politics. Transactions of the Institute of British Geographers 33(2):157-172. http://dx.doi.org/10.1111/ j.1475-5661.2008.00293.x 
Lejon, A. G. C., B. M. Renöfält, and C. Nilsson. 2009. Conflicts associated with dam removal in Sweden. Ecology And Society 14 (2):4. http://dx.doi.org/10.5751/ES-02931-140204

Lewan, L., and T. Söderqvist. 2002. Knowledge and recognition of ecosystem services among the general public in a drainage basin in Scania, Southern Sweden. Ecological Economics 42(3):459-467. http://dx.doi.org/10.1016/S0921-8009(02)00127-1

Lewicki, R. 2003. Making sense of intractable environmental conflicts: concepts and cases. Island Press, Washington, D.C., USA.

Luiker, E., J. Culp, A. Yates, and D. Hryn. 2013. Ecosystem metabolism as a functional indicator for assessing river ecosystem health - Application for New Brunswick rivers. Final Report. Canadian Rivers Institute, University of New Brunswick. Prepared for the New Brunswick Environmental Trust Fund, Government of New Brunswick, Fredericton, New Brunswick, Canada.

Mansfield, B., and J. Haas. 2006. Scale framing of scientific uncertainty in controversy over the endangered Steller sea lion. Environmental Politics 15(1):78-94. http://dx.doi. org/10.1080/09644010500418795

McCann, E. J. 2003. Framing space and time in the city: urban policy and the politics of spatial and temporal scale. Journal of Urban Affairs 25(2):159-178. http://dx.doi.org/10.1111/1467-9906. t01-1-00004

Morley, S. A., J. J. Duda, H. J. Coe, K. K. Kloehn, and M. L. McHenry. 2008. Benthic invertebrates and periphyton in the Elwha River Basin: current conditions and predicted response to dam removal. Northwest Science 82(sp1):179-196. http://dx.doi. org/10.3955/0029-344X-82.S.I.179

Moss, T., and J. Newig. 2010. Multilevel water governance and problems of scale: setting the stage for a broader debate. Environmental Management 46(1):1-6. http://dx.doi.org/10.1007/ $\underline{\mathrm{s} 00267-010-9531-1}$

NATIONAL and Corporate Research Associates Inc (CRA). 2016. What was said: final report. NB Power, Fredericton, New Brunswick, Canada. [online] URL: https://www.nbpower.com/ media/689752/what_was_said_report_mactaquac.pdf

NB Power. 2014. Mactaquac life achievement project. NB Power, Fredericton, New Brunswick, Canada. [online] URL: https:// www.nbpower.com/html/en/about/future/mactaquac.html

NB Power. 2015. Your feedback: What we heard at our Mactaquac Project open houses. NB Power, Fredericton, New Brunswick, Canada.

NB Power. 2016. Considering the future of Mactaquac. NB Power, Fredericton, New Brunswick, Canada.

NB Power. 2017. Backgrounder, Mactaquac Generating Station Life Achievement Project. Business Case and Technical Considerations. NB Power, Fredericton, New Brunswick, Canada.

Patrick, M. J., G. J. Syme, and P. Horwitz. 2014. How reframing a water management issue across scales and levels impacts on perceptions of justice and injustice. Journal of Hydrology 519 (PC):2475-2482. http://dx.doi.org/10.1016/j.jhydrol.2014.09.002
Patton, M. Q. 2005. Qualitative research. Pages 1633-1636 in B. S. Everitt and D. C. Howell, editors. Encyclopedia of statistics in behavioral science. John Wiley \& Sons, Chichester, UK. http://dx. doi.org/10.1002/0470013192.bsa514

Peterson, T. R. 2005. Social control frames: opportunities or constraints? Environmental Practice 5(3):232-238.

Poff, N. L., and D. D. Hart. 2002. How dams vary and why it matters for the emerging science of dam removal. BioScience 52 (8):659-668. http://dx.doi.org/10.1641/0006-3568(2002)052[0659: HDVAWI]2.0.CO:2

Royal Bank of Canada (RBC). 2017. New Brunswick Budget 2017. RBC, Toronto, Ontario, Canada.

Reed, M. G., and S. Bruyneel. 2010. Rescaling environmental governance, rethinking the state: a three-dimensional review. Progress in Human Geography 34(5):646-653. http://dx.doi. org/10.1177/0309132509354836

Reed, M. S. 2008. Stakeholder participation for environmental management: a literature review. Biological Conservation 141 (10):2417-2431. http://dx.doi.org/10.1016/j.biocon.2008.07.014

Reilly, K. H., and J. F. Adamowski. 2017. Stakeholders' frames and ecosystem service use in the context of a debate over rebuilding or removing a dam in New Brunswick, Canada. Ecology and Society 22(1):17. http://dx.doi.org/10.5751/ ES-09045-220117

Sayre, N. F. 2005. Ecological and geographical scale: parallels and potential for integration. Progress in Human Geography 29 (3):276-290. http://dx.doi.org/10.1191/0309132505ph546oa

Sayre, N. F., and A. V. Di Vittorio. 2009. Scale. Pages 19-28in R. Kitchin and N. Thrift, editors. International encyclopeadia of human geography. Vol. 1. Elsevier, Oxford, UK.

Scheufele, D. 1999. Framing as a theory of media effects. Journal of Communication 49(1):103-122. http://dx.doi.org/10.1111/ j.1460-2466.1999.tb02784.x

Schön, D., and M. Rein. 1995. Frame reflection: toward the resolution of intractable policy controversies. Basic Books, New York, New York, USA.

Sherren, K., T. M. Beckley, J. R. Parkins, R. C. Stedman, K. Keilty, and I. Morin. 2016. Learning (or living) to love the landscapes of hydroelectricity in Canada: eliciting local perspectives on the Mactaquac Dam via headpond boat tours. Energy Research \& Social Science 14:102-110. http://dx.doi.org/10.1016/j.erss.2016.02.003

Shmueli, D. F., M. Elliott, and S. Kaufman. 2006. Frame changes and the management of intractable conflicts. Conflict Resolution Quarterly 24(2):207-218. http://dx.doi.org/10.1002/crq.169

Si, Z. 1993. A theoretical framework for social impact analysis with special reference to population relocation at the Mactaquac Dam project on the Saint John River. Dissertation. Dalhousie University, Halifax, Nova Scotia, Canada.

Sica, C. E. 2015. Stacked scale frames: building hegemony for fracking across scales. Area 47(4):443-450. http://dx.doi. org/10.1111/area.12213 
Stantec. 2016. Mactaquac Project comparative environmental review report. Stantec Consulting Ltd., Fredericton, New Brunswick, Canada.

Statistics Canada. 2017. Census profile, 2016 census. Statistics Canada, Ottawa, Ontario, Canada.

Strauss, A., and J. Corbin. 1998. Basics of qualitative research techniques and procedures for developing grounded theory. Second edition. SAGE, London, UK.

Susskind, L. 2013. Water and democracy: new roles for civil society in water governance. International Journal of Water Resources Development 29(4):666-677. http://dx.doi. org/10.1080/07900627.2013.781914

Termeer, C. J. A. M., A. Dewulf, and M. Van Lieshout. 2010. Disentangling scale approaches in governance research: comparing monocentric, multilevel, and adaptive governance. Ecology and Society 15(4):29. http://dx.doi.org/10.5751/ ES-03798-150429

Towers, G. 2000. Applying the political geography of scale: grassroots strategies and environmental justice. Professional Geographer 52(1):23-36. http://dx.doi.org/10.1111/0033-0124.00202

van Hulst, M., and D. Yanow. 2016. From policy "frames" to "framing": theorizing a more dynamic, political approach. American Review of Public Administration 46(1):92-112. http://dx. doi.org/10.1177/0275074014533142

van Lieshout, M. 2014. Framing scales and scaling frames: the politics of scale and its implications for the governance of the Dutch intensive agriculture. Dissertation. Wageningen University, Wageningen, The Netherlands.

van Lieshout, M., A. Dewulf, N. Aarts, and C. Termeer. 2011. Do scale frames matter? Scale frame mismatches in the decision making process of a "mega farm" in a small Dutch village. Ecology and Society 16(1):38. http://dx.doi.org/10.5751/ES-04012-160138

van Lieshout, M., A. Dewulf, N. Aarts, and C. Termeer. 2012. Doing scalar politics: interactive scale framing for managing accountability in complex policy processes. Critical Policy Studies 6(2):163-181. http://dx.doi.org/10.1080/19460171.2012.689736

van Lieshout, M., A. Dewulf, N. Aarts, and C. Termeer. 2014. The power to frame the scale? Analysing scalar politics over, in and of a deliberative governance process. Journal of Environmental Policy and Planning 1-24. http://dx.doi. org/10.1080/1523908X.2014.936581

Van Looy, K., T. Tormos, and Y. Souchon. 2014. Disentangling dam impacts in river networks. Ecological Indicators 37(PART A):10-20. http://dx.doi.org/10.1016/j.ecolind.2013.10.006

Vreugdenhil, H., J. Slinger, E. Kater, and W. Thissen. 2010. The influence of scale preferences on the design of a water innovation: a case in Dutch river management. Environmental Management 46(1):29-43. http://dx.doi.org/10.1007/s00267-010-9565-4

Williams, R. W. 1999. Environmental injustice in America and its politics of scale. Political Geography 18(1):49-73. http://dx.doi. org/10.1016/S0962-6298(98)00076-6
World Commission on Dams. 2000. Dams and development. Earthscan, London, UK.

Yin, R. K. 2003. Case study research: design and methods. SAGE, Thousand Oaks, California, USA.

Zald, M. N. 1996. Culture, ideology and strategic frames. Pages 261-274 in D. McAdam, J. D. McCarthy, and M. N. Zald, editors Comparative perspectives on social movements: political opportunities, mobilizing structures, and cultural framings. Cambridge University Press, Cambridge, UK. 